\title{
ROLE OF EXOGENOUS ADVANCED GLYCATION END PRODUCTS IN ORAL CARCINOGENESIS: A REVIEW
}

\author{
ARULMOZHI NANDAKUMAR ${ }^{1 *}$, PRIYADHARSINI N ${ }^{1}$, RAMESH KUMAR ${ }^{1}{ }^{1}$, MURUGAN MAHESH ${ }^{2}$ \\ ${ }^{1}$ Department of Oral Pathology, SRM Dental College, Ramapuram, Chennai, Tamil Nadu, India. ${ }^{2}$ Department of Ophthalmology, SRM \\ Medical College, Kattangulathur, Chennai, Tamil Nadu, India. Email: docarulmozhi@gmail.com
}

Received: 24 October 2017, Revised and Accepted: 22 November 2017

\section{ABSTRACT}

Objective: Glycation is the chemical reaction involving the modification of proteins and amino acids in the presence of reducing sugars, and advanced glycation end products (AGEs) are heterogeneous compounds whose accumulation is implicated as the pathogenesis in various chronic diseases.

Method: A narrative review of all the articles known to the authors was conducted.

Results: Tobacco and diet are the two major sources of exogenous AGE and the foremost characteristic of the glycotoxins, formed from tobacco curing reaction, is their high reactivity and innate ability to cross the cell membrane and bind with serum proteins and formation of adducts with amino acids of nucleic acids. Binding of AGEs to their receptor for AGE activates mechanisms which favor production of reactive oxidative species and proinflammatory cytokines. AGEs are also implicated as key players in cell survival, proliferation, invasion, and metastasis of tumor cells and also significantly contribute to genotoxicity. Salivary estimation of AGEs is a promising exposition to monitor the prognosis of oral pre-cancers and cancer.

Conclusion: This review aims in eliciting the role of AGEs in pathogenesis of oral cancer and its possible development as a biomarker to monitor the initiation and progression of cancer.

Keywords: Advanced glycation end products, Exogenous advanced glycation end products, Tobacco, Carcinogenesis

(C) 2018 The Authors. Published by Innovare Academic Sciences Pvt Ltd. This is an open access article under the CC BY license (http://creativecommons. org/licenses/by/4. 0/) DOI: http://dx.doi.org/10.22159/ajpcr.2018.v11i3.22961

\section{INTRODUCTION}

Glycation is the chemical reaction involving the modification of proteins and amino acids in the presence of reducing sugars such as glucose and fructose. This mechanism termed as Maillard reaction whose end products comprise non-enzyme-mediated cross-links forming heterogeneous compounds known as advanced glycation end products (AGEs). As a result of the Maillard reaction, a Schiff base is formed which undergoes modification of its bonds in Amadori rearrangement to form chemically distinct stable AGEs [1]. The term AGE broadly includes the products of both glycoxidation and lipid peroxidation pathway. The origin of AGE may be both endogenous and exogenous and though in vivo AGEs are poorly characterized due to their highly reactive nature, most popularly studied molecules include N-carboxy-methyl lysine (CML), pyrraline, and pentosidine [2,3].

\section{Exogenous AGEs}

Tobacco and diet are the two major sources of exogenous AGE. Cooking animal food at high temperatures for extended time which gives its characteristic taste and aroma also results in highly reactive precursors and dietary AGEs like CML [4]. Since tobacco curing also involves processes similar to Maillard reaction, they promote accumulation of AGEs which contributes to cardiovascular disease and cancer in tobacco smokers [5]. The foremost characteristic of glycotoxins, formed from tobacco curing reaction, is their high reactivity and ability to form AGEs within few hours as opposed to simple sugars which takes few days to weeks. They have innate ability to cross the cell membrane and bind with serum proteins. Glycotoxins may also explain the increased incidence of cancer in cigarette smokers through the formation of adducts with amino acids of nucleic acids [6]. There are numerous methods to estimate AGEs from bodily fluids and tissue samples (Table 1).
It has been proposed that chronic accumulation of AGEs in tissue has been implicated in various chronic diseases such as diabetes mellitus and cardiovascular disease, connective tissue disorder like rheumatoid arthritis, and neurological diseases such as Alzheimer's and end-stage renal diseases [7].

Exogenous AGEs have numerous cellular effects which alter signaling pathways and cause structural changes (Table 2).

The pathophysiogenesis of tissue damage by AGEs is attributed to two main pathways, namely, alteration of basic protein structures by covalent bondage with tissue proteins, nucleic acids, and lipids and second through the activation of receptor-mediated mechanisms involving receptor for AGE (RAGE) which favor production of reactive oxidative species and proinflammatory cytokines [8].

The principal pathway of elimination of AGE bound tissue is through tissue macrophages which possess dedicated AGE-binding receptors. The small AGE-peptides, thus released after degradation is eliminated by creatinine dependent clearance in kidneys. Any decline in kidney function, thus actively contributes to the accumulation of AGE and is the basis of vascular diseases [9]. Previous studies have shown that insulin also plays an important role in AGE elimination from plasma and insulin which has vasculoprotective function is involved in exocytosis of AGE proteins by liver endothelial cells which express macrophage scavenger receptor. Thus, diabetes mellitus which affects insulin metabolism encompass accumulation of AGEs in tissue leading to secondary microvascular complications [10].

\section{AGE-RAGE interaction}

The accumulation of AGE depends on the availability glycotoxins, AGE precursors, and reactive amino groups. AGE formation is assisted by reactive oxygen species (ROS), and AGE-RAGE interaction, in turn, 
Table 1: Methods of estimation of AGE

\begin{tabular}{|c|c|c|c|c|}
\hline $\begin{array}{l}\text { Spectrofluorimetric } \\
\text { methods }\end{array}$ & HPLC Methods & ELISA methods & LS-MS Technique & $\begin{array}{l}\text { Western Blot } \\
\text { method }\end{array}$ \\
\hline $\begin{array}{l}\sim \text { Total AGE } \\
\text { determination-370 } \mathrm{nm} \\
\text { and } 440 \mathrm{~nm} \text { - Varian } \\
\text { Spectrofluorometer } \sim \text { In vitro } \\
\text { glycation of bovine serum } \\
\text { albumin } \sim \text { BSA-glucosa } \\
\text { assay } \sim \text { BSA-MGO } \\
\text { assay } \sim \text { In vitro glycation of } \\
\text { proteins }\end{array}$ & $\begin{array}{l}\text { estimation in serum and urine } \sim \text { flow } \\
\text { injection assay-detecting small size } \\
\text { AGE-peptide } \sim \text { Pentosidine-excitation } \\
335 \mathrm{~nm} \text { and emission } 385 \mathrm{~nm}\end{array}$ & $\begin{array}{l}\sim \text { CML estimation } \\
\text { absorbance at } 405 \\
\text { nm } \sim \text { Plasma AGE } \\
\text { evaluation } \sim \text { Estimation of } \\
\text { Renal CML }\end{array}$ & $\begin{array}{l}\sim \text { Pentosidine, } \\
\sim \text { GOLD } \sim \text { MOLD } \sim \mathrm{CML}\end{array}$ & $\begin{array}{l}\sim \text { AGE modified } \\
\text { proteins in } 1 D \text {-SDS } \\
\text { gels } \sim \text { AGE-modified } \\
\text { proteins in } \\
\text { Dot-immunobinding } \\
\text { assay }\end{array}$ \\
\hline
\end{tabular}

AGEs: Advanced glycation end products, CML: Carboxymethyl lysine

Table 2: Cellular effects of advanced glycation end products

Effects of advanced glycation end products

\begin{tabular}{|c|c|}
\hline Upregulation/increase & Downregulation/decrease \\
\hline \multicolumn{2}{|l|}{ 1.Lipid peroxidation } \\
\hline Increased ROS production & Superoxide dismutase function \\
\hline Endothelin-1 & Nitric acid \\
\hline \multicolumn{2}{|l|}{ Inappropriate cellular activity } \\
\hline \multicolumn{2}{|l|}{ Cytokine secretion } \\
\hline \multicolumn{2}{|l|}{ VCAM-1 } \\
\hline \multicolumn{2}{|l|}{ Mitogenesis } \\
\hline \multicolumn{2}{|l|}{ Stimulation of T cells } \\
\hline \multicolumn{2}{|l|}{ Interferon $\gamma$} \\
\hline \multicolumn{2}{|l|}{ Thrombosis and fibrinolysis } \\
\hline Tissue factor & Thrombomodulin \\
\hline Increased platelet aggregation & Reduced platelet survival \\
\hline \multirow[t]{2}{*}{ Fibrin stabilization } & Reduced sensitivity to plasmin \\
\hline & Reduced thrombin activity \\
\hline \multicolumn{2}{|l|}{ Structural changes } \\
\hline \multicolumn{2}{|l|}{$\begin{array}{l}\text { Collagen disorder leading to } \\
\text { premature ageing }\end{array}$} \\
\hline \multicolumn{2}{|l|}{$\begin{array}{l}\text { Irreversible collagen linkage } \\
\text { in proteins }\end{array}$} \\
\hline $\begin{array}{l}\text { Cell membrane and matrix } \\
\text { changes in diabetic kidneys }\end{array}$ & \\
\hline
\end{tabular}

ROS: Reactive oxygen species

activates NADPH-oxidase resulting in increased peroxynitrites and inactivation of functional proteins. ROS production upregulates nuclear transcription factor kappa B (Nf- $\kappa \mathrm{B})$ leading to increase in nitrosative stress [11,12]. Thus, a vicious cycle between antioxidant depletion and ROS-mediated advanced glycation end products which promote oxidative stress by reactive oxygen and nitrating species causes permanent protein damage in cells.

Exogenous AGEs are allied with proinflammatory and oxidative effects and dietary restriction of AGE results in reduction in inflammation [13]. $\mathrm{Nf}-\kappa \mathrm{B}$ is the key player in AGE-related pathogenesis which correlates immunity to inflammation through mitogen-activated protein kinase pathway (MAPK) [14]. As a master regulator, NF- $\kappa B$ is able to upregulate the expression of a variety of inflammation-related mRNAs, COX-2 (cyclooxygenase-2) and proinflammatory cytokines such as tumor necrosis factor- $\alpha$ and interleukin-6 (IL-6). Another pathway by which RAGE mediates inflammation is Jun-N-terminal kinase signaling which upregulates transcription activity of activator protein- 1 which codes for proinflammatory cytokines and factors [15-17].

\section{AGE and sustained cell survival}

Reactive glycation products derived from chewing tobacco extract and smoke are capable of interacting with proteins rapidly to form AGEs and have been detected in higher levels in smokers than controls irrespective of diabetes [18]. Such AGEs promote "metabolic memory" in the body, wherein previous exposure to tobacco glycotoxins causes damage to tissue that is not reversed by cessation of habit [19].

RAGE is a pattern recognition receptor that recognizes ligands on the surfaces of previously damaged cells and promotes tumorigenesis. AGE-RAGE interaction promotes the expression of IL- 6 which acts as an autocrine growth factor for these cells [20,21]. In vitro studies reveal increased expression of matrix metalloproteinases (MMPs) by AGE through the activation of MAPK signaling and RAGE, in addition, being an inflammatory modulator is theorized to promote tumor survival by sustained autophagy and apoptosis inhibition [22,23]. All these collectively contribute to cells which ultimately escape cell cycle surveillance and survive beyond their stipulated time, contributing to tumorigenesis.

\section{AGE and cellular proliferation}

The ROS generated by AGE stimulates proliferation of endothelial cells, mediated by vascular endothelial growth factor, and is essential for tumor neoangiogenesis. Several studies implicate that VEGF expression associated with angiogenesis and macrophage infiltration are the key processes in tumorigenesis [24,25]. Controversially, AGE also inhibits cyclin production and through activation of plasminogen activator inhibitor-1 resulting in risk of thrombogenesis, obliteration of blood supply leading to hypoxic tumor environment [26]. Hypoxia itself is a potent modulator of hypoxia inducing factor HIF-1which has shown to play a key role in tumor angiogenesis and growth in cancers of the breast [27]. Increased expression of carbohydrate responsive element binding protein (ChREBP) which promotes glycotic and anabolic reactions is induced by AGE-RAGE signaling pathway and contribute to the proliferation of cancer cells. The DNA-binding activity of ChREBP is aided in a high glucose-dependent environment wherein ChREBP which is localized in the cytoplasm translocates into the nucleus [28].

\section{AGE and tumor invasion and metastasis}

In a study by Sasahira et al., immunohistochemical expression of RAGE in oral squamous cell carcinoma (OSCC) showed significant association with depths of invasion and recurrence rates of OSCC. Higher expression of RAGE was appreciated at the invasive front of the tumor. Along with it an increase in activation of MMPs at the tumor invasive front contributes to the invasiveness of the carcinoma [23].

Takino et al. studied the relationship between glyceraldehyde-derived AGE and increase in cell migration-mediated through RAGE expression and secretion of MMPs, both MMP-2 and MMP-9. Expression of MMP has been associated with cell migration and metastasis in OSCC [29-31]. Thus, AGEs through their influence on MMPs contribute to both tumor aggressiveness and invasive nature of the tumor.

\section{AGE and genotoxicity}

A study by Van heist et al. demonstrated the presence of CML and argpyrimidine in various cancer tissues and their expression varied with tumor type. Studies by Stopper et al. revealed that the AGE-RAGE binding can directly contribute to loss of DNA integrity. This statement is 
complimented by the detection oxidative DNA damage marker, 8-0HdG after AGE treatment of vascular smooth muscle cells [32,33]. AGEinduced expression of NF-kB leads to the activation of angiotensinogen subsequently increasing intracellular ROS leading to DNA damage.

\section{Role of salivary AGE estimation in oral cancer}

Estimation of AGEs in saliva has been previously studied with the aim of determining salivary oxidative stress in numerous oral diseases, namely, periodontitis and dental caries $[34,35]$. Saliva is a convenient alternate body fluid to measure parameters that mirror in the blood. The exchange of plasma and saliva occurs in the salivary ducts with intervening epithelium which is selectively permeable. Measurement of AGE is an excellent marker of carbonyl stress. Pentosidine and CML can be measured using ELISA or Western blotting methods. Their determination is based on the detection of specific fluorescence of AGEs at $370 \mathrm{~nm}$ excitation and $440 \mathrm{~nm}$ emissions.

A study by Vlková et al., in 2012, on oxidative stress in patients with premalignant oral diseases (PMODs) and matched controls concluded that salivary AGE is significantly higher in patients with PMODs compared to controls without oral lesions [36]. Markers of lipoperoxidation and carbonyl stress were also increased in the patients with PMODs which theorized the pathogenesis of malignant transition of PMODs to carcinomas. Thus, AGE plays a key role in pathogenesis of oxidative stress which increases its role in cancer $[37,38]$.

\section{CONCLUSION}

There is substantial evidence that exogenous AGE and RAGE-AGE axis could play a contributory role in the development of cancer. AGEs seem to influence the proliferation and invasion of the tumor through their proangiogenic and inflammatory effects. Till date, there is a search for a definitive marker to indicate the malignant transformation of PMODs to carcinoma and salivary AGE estimation is a promising path to the same. Further, research is essential in larger population to evaluate the usefulness of AGE estimation as a marker for early diagnosis and prognosis in PMODs and OSCC. Exogenous AGEs in OSCC can provide insight into its pathogenesis or early changes in cancer, and therapeutic methods could be built to target them at the bud.

\section{ACKNOWLEDGMENT}

We would like to acknowledge the help of Mrs. Pushpa, Department of Biochemistry, SRM Dental College, for her guidance and encouragement while conceiving this article.

\section{AUTHOR CONTRIBUTIONS}

None

\section{CONFLICT OF INTEREST}

The authors declare that they have no conflict of interest.

\section{REFERENCES}

1. Dyer DG, Dunn JA, Thorpe SR, Bailie KE, Lyons TJ, McCance DR, et al. Accumulation of maillard reaction products in skin collagen in diabetes and aging. J Clin Invest 1993;91:2463-9.

2. Hodge JE. Dehydrated foods, chemistry of browning reactions in model systems. J Agric Food Chem 1953;1:928-43.

3. Booth AA, Khalifah RG, Todd P, Hudson BG. In vitro kinetic studies of formation of antigenic advanced glycation end products (AGEs). Novel inhibition of post-amadori glycation pathways. J Biol Chem 1997;272:5430-7.

4. Goldberg T, Cai W, Peppa M, Dardaine V, Baliga BS, Uribarri J, et al. Advanced glycoxidation end products in commonly consumed foods. J Am Diet Assoc 2004;104:1287-91.

5. Cerami C, Founds H, Nicholl I, Mitsuhashi T, Giordano D, Vanpatten S, et al. Tobacco smoke is a source of toxic reactive glycation products. Proc Natl Acad Sci U S A 1997;94:13915-20.

6. Bucala R, Makita Z, Koschinsky T, Cerami A, Vlassara H. Lipid advanced glycosylation: Pathway for lipid oxidation in vivo. Proc Natl
Acad Sci U S A 1993;90:6434-8.

7. Chiarelli F, de Martino M, Mezzetti A, Catino M, Morgese G, Cuccurullo F, et al. Advanced glycation end products in children and adolescents with diabetes: Relation to glycemic control and early microvascular complications. J Pediatr 1999;134:486-91.

8. Yan SF, Ramasamy R, Schmidt AM. The RAGE axis: A fundamental mechanism signaling danger to the vulnerable vasculature. Circ Res 2010;106:842-53.

9. Forbes JM, Cooper ME, Oldfield MD, Thomas MC. Role of advanced glycation end products in diabetic nephropathy. J Am Soc Nephrol 2003; 14:S254-8.

10. Sano H, Higashi T, Matsumoto K, Melkko J, Jinnouchi Y, Ikeda K, et al. Insulin enhances macrophage scavenger receptor-mediated endocytic uptake of advanced glycation end products. J Biol Chem 1998;273:8630-7.

11. Singh R, Barden A, Mori T, Beilin L. Advanced glycation end-products: A review. Diabetologia 2001;44:129-46.

12. Mizutani K, Ikeda K, Ito T, Tamaki K, Nara Y, Yamori Y. Protective effect of inducible type nitric oxide synthase against intracellular oxidative stress caused by advanced glycation end-products in vascular smooth muscle cells from stroke-prone spontaneously hypertensive rats. J Hypertens 2000;18:1071-9.

13. Vlassara H, Cai W, Crandall J, Goldberg T, Oberstein R, Dardaine V, et al. Inflammatory mediators are induced by dietary glycotoxins, a major risk factor for diabetic angiopathy. Proc Natl Acad Sci U S A 2002;99:15596-601.

14. Lander HM, Tauras JM, Ogiste JS, Hori O, Moss RA, Schmidt AM, et al. Activation of the receptor for advanced glycation end products triggers a $\mathrm{p} 21$ (ras)-dependent mitogen-activated protein kinase pathway regulated by oxidant stress. J Biol Chem 1997;272:17810-4.

15. Perkins ND. Integrating cell-signalling pathways with NF- $\mathrm{BB}$ and IKK function. Nat Rev Mol Cell Biol 2007;8:49-62.

16. Rosales-Corral S, Reiter RJ, Tan DX, Ortiz GG, Lopez-Armas G. Functional aspects of redox control during neuroinflammation. Antioxid Redox Signal 2010;13:193-247.

17. Bianchi R, Kastrisianaki E, Giambanco I, Donato R. S100B protein stimulates microglia migration via RAGE-dependent up-regulation of chemokine expression and release. J Biol Chem 2011;286:7214-26.

18. Nicholl ID, Stitt AW, Moore JE, Ritchie AJ, Archer DB, Bucala R, et al. Increased levels of advanced glycation endproducts in the lenses and blood vessels of cigarette smokers. Mol Med 1998;4:594-601.

19. Yamagishi S, Matsui T, Nakamura K. Possible involvement of tobaccoderived advanced glycation end products (AGEs) in an increased risk for developing cancers and cardiovascular disease in former smokers. Med Hypotheses 2008;71:259-61.

20. Heijmans J, Büller NV, HoffE, Dihal AA, van der Poll T, van Zoelen MA, et al. Rage signalling promotes intestinal tumourigenesis. Oncogene 2013;32:1202-6.

21. Miki S, Kasayama S, Miki Y, Nakamura Y, Yamamoto M, Sato B, et al. Expression of receptors for advanced glycosylation end products on renal cell carcinoma cells in vitro. Biochem Biophys Res Commun 1993;196:984-9.

22. Bhawal UK, Ozaki Y, Nishimura M, Sugiyama M, Sasahira T, Nomura Y, et al. Association of expression of receptor for advanced glycation end products and invasive activity of oral squamous cell carcinoma. Oncology 2005;69:246-55

23. Sasahira T, Kirita T, Bhawal UK, Yamamoto K, Ohmori H, Fujii K, et al. Receptor for advanced glycation end products (RAGE) is important in the prediction of recurrence in human oral squamous cell carcinoma. Histopathology 2007;51:166-72.

24. Senger DR, Van de Water L, Brown LF, Nagy JA, Yeo KT, Yeo TK, et al. Vascular permeability factor (VPF, VEGF) in tumor biology. Cancer Metastasis Rev 1993;12:303-24.

25. Ueno T, Toi M, Saji H, Muta M, Bando H, Kuroi K, et al. Significance of macrophage chemoattractant protein-1 in macrophage recruitment, angiogenesis, and survival in human breast cancer. Clin Cancer Res 2000;6:3282-9.

26. Enomoto M, Adachi H, Yamagishi S, Takeuchi M, Furuki K, Hino A, et al. Positive association of serum levels of advanced glycation end products with thrombogenic markers in humans. Metabolism 2006;55:912-7.

27. Bondeva T, Heinzig J, Ruhe C, Wolf G. Advanced glycated endproducts affect HIF-transcriptional activity in renal cells. Mol Endocrinol 2013;27:1918-33.

28. Chen H, Wu L, Li Y, Meng J, Lin N, Yang D, et al. Advanced glycation end products increase carbohydrate responsive element binding protein expression and promote cancer cell proliferation. Mol Cell Endocrinol 
2014;395:69-78

29. Takino J, Yamagishi S, Takeuchi M. Cancer malignancy is enhanced by glyceraldehyde-derived advanced glycation end-products. J Oncol 2010;2010:739852.

30. Patel BP, Shah SV, Shukla SN, Shah PM, Patel PS. Clinical significance of MMP-2 and MMP-9 in patients with oral cancer. Head Neck 2007;29:564-72.

31. Ko SY, Ko HA, Shieh TM, Chang WC, Chen HI, Chang SS, et al. Cell migration is regulated by AGE-RAGE interaction in human oral cancer cells in vitro. PLoS One 2014;9:e110542.

32. Stopper H, Schinzel R, Sebekova K, Heidland A. Genotoxicity of advanced glycation end products in mammalian cells. Cancer Lett 2003; 190:151-6

33. Mizutani K, Ikeda K, Nishikata T, Yamori Y. Phytoestrogens attenuate oxidative DNA damage in vascular smooth muscle cells from stroke-prone spontaneously hypertensive rats. J Hypertens 2000;18:1833-40

34. Putta S, Kilari EK. A review on methods of estimation of advanced glycation end products. World J Pharm Res 2015;4:689-99.

35. Tóthová L, Kamodyová N, Červenka T, Celec P. Salivary markers of oxidative stress in oral diseases. Front Cell Infect Microbiol 2015;5:73.

36. Vlková B, Stanko P, Minárik G, Tóthová L, Szemes T, Baňasová L, et al. Salivary markers of oxidative stress in patients with oral premalignant lesions. Arch Oral Biol 2012;57:1651-6.

37. Kshirsagar P, More T, Arvindekar A, Gaikwad N. Antioxidant, antihyperglycemic and antiglycation properties of some Swertia species from Western Ghats. Int J Pharm Pharm Sci 2014;6:303-6.

38. Sangram V, Akula KK, Sangram V. A comparative evaluation of enzymatic antioxidant levels in pre and post therapy patients with oral cancer. Int J Pharm Pharm Sci 2014;6:52-6. 